Publisher homepage: www.universepg.com, ISSN: 2663-7820 (Online) \& 2663-7812 (Print)

https://doi.org/10.34104/cjbis.020.045053

Canadian Journal of Business and Information Studies

Journal homepage: http://www.universepg.com/journal/cjbis

\title{
A Review on Corporate Environmental Reporting (CER): An Emerging Issue in the Corporate World
}

\author{
Md. Jamsedul Islam ${ }^{1}$, Sanjoy Kumar Roy ${ }^{1}$, Masum Miah', and Sumon Kumar Das ${ }^{2}$ \\ ${ }^{1}$ Department of Tourism \& Hospitality Management, Noakhali Science \& Technology University, Noakhali-3814, \\ Chittagong, Bangladesh; and ${ }^{2}$ Department of Business Administration, Noakhali Science \& Technology University, \\ Noakhali-3814, Chittagong, Bangladesh. \\ *Correspondence: mji.thm.nstu@ gmail.com (Md. Jamsedul Islam, Lecturer, Dept. of Tourism \& Hospitality Management, \\ NSTU, Noakhali, Bangladesh)
}

\begin{abstract}
Corporate environmental reporting has been treated as a vital issue in today's corporate world. The current scenario and prospect gives indication that it is going to capture a long lasting position in the bundle of generalpurpose financial statements. The main reason is that the stakeholders prove a sharp interest in such disclosures. To sustain in today's corporate world, every organization has to come forward to protect the environment and it is treated as one of the vital social responsibilities. It is assumed that corporations are the main force to create an environmental crisis so as to pay for this (cost-benefit trade off). But we know reporting is guided by some standards guidelines and measurements and for this we do not have any standards designed for such disclosure. Hence, such reporting is still considered voluntary and has no specific format and design. As it is voluntary disclosure, it often leads to some non-disclosure and mandatory disclosures which in turn leads to minimal disclosures. As it is a question of life and sustainability, environmental disclosure should have considered both types of disclosures; hence, this paper will try to evaluate the conceptual discussion on environmental reporting.
\end{abstract}

Keywords: Environment, Environmental costs, Corporate environmental report, and Environmental reporting.

\section{INTRODUCTION:}

To defend our environment from pollution and to green it, we should take some effective steps which should be concentrated at corporate level. Business Corporate level is the most appropriate center where environmental factors can be focused on and greening activities can be practiced most effectively (Islam, 2020). Environmental issues have flourished in recent decades as a major part of the discussion in the problems of economic growth and development. Such conventions have taken in the norms of global heating like atmospheric, soil and water pollution caused by UniversePG I www.universepg.com industrial actions; and the quick downfall of forest areas, noise pollution and chemical wastes being dumped into oceans and rivers. This problem is generally associated with industrialization and economic growth. In years past, both corporations and individuals often ignored environmental issues (Jones, 2003).

However, stakeholders now feel the consequences of by-products as a probable source of damage to the environment. Most people now acknowledge that sustaining clean air, water and land are more 
significant than to lower the cost of production for consumers. The concept of corporate environmental reporting (CER) is relatively new in Bangladesh. The last few decades of the 20th century have observed an increasing awareness on environmental problems.

Since 1990, environmental reporting has been swiftly established and improved as an effective instrument for environmental legislation. Top corporations around the world, particularly in Australia, Bangladesh, China, Japan, Malaysia, Netherland, New Zealand, Norway and Turkey have employed environmental reporting to promote their eco-competency and supportive productivity.

Due to the raising external squeeze from many stakeholders such as government financial institutions, socially responsible investors and community lobby groups (i.e. members of host communities) among others, now makes companies have more interest in environmental accountability issues. In line with this trend, the rapid increase in environmental costs has now caused companies to concentrate on environmental aspects into managerial decisions at all levels (Shuvro et al., 2019).

In spite of the development of a number of methodologies and practices, ascertaining and reporting environmental monetary operation is still in its minor level. In this context, environmental reporting was newly supposed to as one of the most notable means in adopting a successful environmental management. This indicates that the primitive reporting method, which conducts most environmental cost elements as overhead cost, is inadequate to give managers accurate information for their strategic decision-making (Punte, 1999). Hence, this study basically looked at the range of corporate environmental reporting (disclosure) practice globally, giving emphasis in south Asian countries like India and Bangladesh (Pramanik et al., 2008).

To attain this, the study considers the International Standard Organization disclosure requirements (ISO 14031) which provides willful standards, distinctive policies and principles for environmental reporting (dis-closures) as a basis for balancing.

\section{Literature review}

Gamble et al. (1995) examined the attributes of environmental reporting in $10 \mathrm{~K}$ and annual reports for 234 companies and resolved that companies associated with petroleum refining, perilous waste management, steel works and blast furnaces industries provided the highest attributes of environmental disclosures in their financial statements. ACCA disclosed a report entitled "The State of Corporate Environmental Reporting in Singapore in 2002" that abbreviated the results of a study of the recent annual reports, and stand-alone reports, of 160 enlisted companies and 13 Government Linked Companies (GLCs) and Statutory Boards (SBs). Where, $14 \%$ of listed companies, $23 \%$ of GLCs and SBs disclosed some information about CER in their annual reports and explored the environmental reporting practices of Australian companies, disclosing poor voluntary environmental practices in Australia. Cunningham and Gadenne (2003) examined whether an increase in environmental regulation treats as a pace for changes in annual report disclosure attitude and suggested that environmental regulation treats as a momentum for companies to comprise information on certain environmental phenomenon in the annual report. Tested the connection between corporate features and environmental disclosures by considering a specimen of 100 UK companies drawn from the Center for Social and Environmental Reporting Research (CSEAR). They concluded that the extent of disclosure is relevant with the sales, capital employed, profit, number of employees. As larger and more profitable the firms have disclosed more environmental information.

Lodhia (2002), interpreted environmental reporting in Fiji, concluded that the present exercises in Fiji were far from expectation; with restricted disclosures in corporate annual reports and in these reports, the focus was good . Fortes (2002) examined the importance of environmental reporting in Sweden and concluded that environmental reporting provided remarkable outcomes to businesses and examined 362 Malaysian companies and found that 74 companies (20.44 percent) were environmentally friendly industries and provided environmental information in their annual reports. Bhate (2002) examined the magnitude to 
which consumers of Bangladesh are aware of environmental issues and it was found that Bangladeshis are mostly involved with environmental issues. The study by Thompson and Zakaria (2004) reveals that of the top ten largest Malaysian companies provide information on environmental issues. Bala and Yusuf (2003) examined the annual reports of 249 public limited companies for the year of 2001. They reported that only 26 (10.4 percent of the total) companies reveal environmental facts in the BOD's Report or in the CEO's Statement or elsewhere in their annual reports.

Rajapakse (2003) carried out an experiment on environmental disclosure practices in Sri Lanka and hardly found any significant improvement in social and environmental reporting. Surmenand Kaya (2003) studied environmental reporting and reporting in Turkey and found that like other developing countries, Turkey has not seen environmental issues as a priority. Nuhoglu (2003) also examined environmental disclosure practices in Turkish companies and reported that Turkish companies' reports were lower standard and prepared much less seriously vis-à-vis multinational companies' reports. Ahmad and Sulaiman (2004) examined the quality and way of willful environmental disclosures in annual reports for the year 2000 by Malaysian companies pertaining to edifice and manufacturing product industries and inferred that the level of environmental disclosure was very poor and was spread throughout the report without any centralization. Thomson and Zakarai (2004) examined the quality, character and appearance of corporate social and environmental disclosure made by Malaysian companies and revealed that the corporate environmental reporting of these companies was poor in quality and low in quantity.

Shil and Iqbal (2005) examined 121 manufacturing companies listed on the Dhaka Stock Exchange (DSE) and reported that merely 13 companies (11 percent of 121 companies) disclosed qualitative environment related information in the Directors' Report in their annual reports. Rahman and Muttakin (2005) examined 125 manufacturing companies listed on the Chittagong Stock Exchange (CSE) for the year 2003/2004 and reported that merely 5 companies (4 percent of 125 companies) expressed environmental information in their annual reports. Bose (2006) analyzed 5 years' annual reports of 11 PetroBangla and concluded that in 1998-199 and 1999-2000, only $45.45 \%$ and in 2000-01, 63.63\% and in 2001-02 and 2002-03, only $81.81 \%$ of PetroBangla companies reveled environmental information in their annual reports.

\section{What is Corporate Environmental Reporting (CER)?}

Corporate environmental reporting (CER) which is the sub part of Corporate reporting, has been abroad since the 1980s, and is well known for using as a management technical tool for a variety of purposes, for instance flourishing environmental performance, minimizing costs, investing in technical knowhow, developing greener processes and products, and framing decisions related to corporation's business activities. Corporate environmental reporting is an innovative sustainability initiative that has been defined as that aspect of reporting which has to do with the identification, allocation and analysis of objective flows and their allied money flows by using corporate environmental reporting systems to provide insight in environmental impacts and attached with financial consequences. It is a reporting tool that can be used to boost the National income reporting, financial reporting, and or internal business managerial reporting. Environmental or green reporting involves measuring the environmental execution of an organization, including government bodies and manufacturers in economic terms (Rahman and Rahman, 2020). It is a type of cost benefit analysis system, which relates to the monetary assessment of environmental costs associated with the development and operational activities and the economic benefits of good environmental management. It is also treated as a broader issue to implement sustainable business habits and to preserve natural resources for next generations. The term corporate environmental reporting is often used within the reporting and environmental management. It is a broader term that is also anticipated with the provision of environmental performance related information to stakeholders both within and outside an organization. 
Bennett and James (1998:33) defined corporate environmental reporting as the systematic reporting by disclosing financial and non-financial information in order to maximize corporate environmental and economic performance and to attain sustainable business. In spite of this definition, the United State Environmental Protection Agency, (1995:18), defined corporate environmental reporting as "an important function to bring attention the environmental cost to corporate stakeholders who may be capable and convinced to identify the ways of minimizing or avoiding those costs while at the same time enhancing environmental quality." The International Federation of Accountants (1998:4) provided their opinion "Corporate environmental reporting is the environment related reporting system and practice that manages the environment and economic performance through the development and implementation of appropriate environmental related issues. While this may include reporting and auditing in some companies, corporate environmental reporting typically involves life cycle costing, full-cost reporting, benefits assessment, and strategic planning for environmental management." A complete definition given by the United Nations Expert Working Group (2000) on corporate environmental reporting, this more specially highlighted both the physical and monetary sides of corporate environmental reporting.

This definition was evolved by international consensus of the group members, representing 30 nations. According to them, corporate environmental reporting involves the identification, accumulation, exploration and the use of two forms of information for decisionmaking. However, from definitions provided above, Corporate environmental reporting(CER) can be treated as a management tool which can be used for a various purposes, such as enhancing environmental performance, minimizing costs, investing in cleaner technical knowhow, developing greener processes and products, and taking informed decisions relating to product mix, product pricing and product retention. In addition, corporate environmental reporting can be treated as the generation, exploration and use of environmental information in order to improve corporate environmental and economic performance.
CER, why it is: If We observe the doings of the firms at corporate level and of the government at state level, they perform many economic activities to reduce the effect of environmental pollution, to shape their products to be friendly to the environment, to conserve environment from being polluted and finally to green our environment. Such activities for greening our environment are: Using environmental friendly materials in production process which results in higher cost in production; Using high technology in production process so that the causes of pollution to the environment can be nullified or otherwise be minimized; Creating public awareness about the causes of pollution ; Meeting social responsibilities; Reducing environmental degradation; Reconstructing and rehabilitating the victims of environmental hazards; Doing afforestation; Most of the above greening activities and others relating to it are not brought into account while preparing financial statements at corporate level and calculating Gross Domestic Production (GDP) at state level and hence the conventional accounting system does not provide a true financial position (Islam and Alam, 2019).

CER also helps to add the followings in GDP growth calculation which conventional national accounts do not take into account: Reduction of flood damage and drought losses by increasing forest density and forest cover; Reduction of ambient air pollution by legislating cleaner fuels greener cities; Increasing human capital (i.e. earning potential) through education; The loss of lives and livelihoods due to the natural disaster; Use of solid fuels which is more than 90\% in Bangladesh; Traditional national accounts largely neglect: newly observed shortages of natural resources, which threaten the sustainability of economic performance and growth, and Environmental deterioration as an 'external' (social) cost of economic action. Further critique criticizes a possible alteration from measuring environmental conservation expenditures as a rise in national income; nevertheless such 'defensive expenditure' look after, rather than rise in expenditure, the welfare of society.

\section{Why Firms Should Decide to Address CER?}

This section describes the factors, which include management commitment, support to related 
programs, and customer demands that led firms to address CER.

Management Commitment: Firm's senior management initiates the Design for the Environment (DfE) program as part of its policy for environmental protection. The architects of the firm's DfE program see economic considerations as a key component and establish a CER Team to help implement DfE. The CER Team believes that CER can support the achievement of firm's environmental policies by: Supplying relevant cost data to understand and improve environmentally Impactive processes, and drive desired behavior towards designing environmentally preferable products and services; Providing information to support the most cost-effective solutions to preventing and/or meeting environmental compliance needs; and Providing evidence of compliance with environmental standards (both regulatory and voluntary). Providing management with environmental cost data facilitates making better environmental and business decisions. In this way, CER can help firms to avoid potential environmental liabilities, reduce costs, and minimize its impact on the environment. CER has been described as "essential not only to give the environmental projects an equal chance of receiving needed resources, but also to get an accurate description of the true environmental costs associated with the manufacture of each product".

Support to Related Firm's Initiatives: The prospects for adopting CER have been enhanced by its relationship to several important programs and activities at firm's corporate level, including Total Quality Management (TQM), Design for Environment (DfE), and Activity-Based Costing and Management $(\mathrm{ABC} / \mathrm{M})$. This section summarizes the relationships seen at corporate level between CER and each of these programs.

Total Quality Management: Top management at corporate level has emphasized that its environmental goals are based on Total Quality Management (TQM) principles. Firm's Cost of Quality (COQ) model that focuses on elimination through source contraction first, followed by reuse, recycling, and treatment with removal as the last choice. For example, firms view the contraction of scrap as a means to minimize costs. Top management can identify three important means that enhance the environmental management approaches to guide TQM, noting that they strengthen: Customer comport through upgraded relationships, which appear because of meeting or surpassing environmental anticipation; Organizational effectiveness, by including everyone in participating the mission to improve environmental quality; and Firm's competitiveness, because when a firm addresses social concerns such as its impact on the environment, it significantly increases value for its customers.

Design for Environment (DfE): This signals for environmental expectation to be integrated into product design from the origin. Designing for the environment is a key in being competitive in processes, products, and services of a firm.

\section{Global Corporate Environmental Reporting} Practices: Responsibility towards the environment has become one of the most crucial areas of social responsibility. With the idea of continuous development catching on fast, corporate and industrial units all over the world are increasingly assimilating the environmental ingredients in their day-to-day business activities. Their view is clear in the perception that along with quality, safety of the environment too, is a significant variable making a business successful. Concern has been raised for environmental deterioration, which has occurred mainly in the form of contamination of various means, viz. air, water, sound, soil erosion, deforestation, etc. It harms human health, decreases economic yield and leads to a deficit of comports. Both environmental preservation and economic advancement are a matter of great concern nowadays. Therefore, an appropriate equilibrium is necessary between the two. For this reason, careful judgment of costs and benefits of environmental contamination is required in order to find the ranges of environmental deterioration and the required level of advancement.

CER (also known as Environmental Accounting/ Resource Accounting/Integrated Economic and Environmental Accounting/Sustainability Accounting) is an attempt to identify and bring into light the 
resources utilized and costs imposed on the ecosystem by the activities of corporate houses (Adagye and Abubakar, 2018). It is a systematic tool of accounting developed to report the costs and benefits provided by the environment to a business entity and benefits and costs contributed to the environment by the same business entity. Hence, CER indicates a process of economically admitting the advantages originated by an organization from the environment and initiating remedial measures to reduce the possibility of environmental pollution through its business activities. The cost incurred on such remedial measures is known as shadow pricing, and is recorded through the CER practice. Initial global surveys revealed that environmental reporting is primarily a large-company matter.

The disclosure of environment related information is ad hoc and usually involves only good news, but there have been signs of innovative and transparent attempts by some corporations. Similarly, these analyses have recommended environmental reports which are provisional, sectional, public interests driven, noncomparative, wanting independent authentication, and are mainly qualitative and descriptive. The KPMG international environmental consulting group together with the Institute for Environmental Management at the University of Amsterdam carried out international surveys on environmental reporting in the years 1994, 1999, and 2005. This survey observed the reporting practices in the largest 250 companies in the world (19 countries) coupled with an analysis of practices of the top 100 companies in 11 countries. Findings recommend an increase in the use of environmental disclosures, the influences of the industrial zone in clarifying environmental disclosure, and that a fixed proportion of the reports (18\%) were independently verified (KPMG, 1999).

The GRI is an international multi-stakeholder effort by the Coalition for Environmentally Responsible Economies (CERES) and the UNEP toward developing globally applicable guidelines for reporting on the economic, social, and environmental performance of corporations, governments, and non-governmental organizations (Kolk, 1999 and GRI, 2000). It is expected that these guidelines would improve disclosure of environmental issues in corporate annual reports (Chowdhury and Hamid, 2013). The first country to recommend compulsory environmental reporting was Denmark followed by other European Nations some of which include Holland, Sweden and Norway, (Kolk, 1999 and KPMG, 1999).

In the United States, under the Toxics Release Inventory (TRI) provisions, companies disclosed environmental issues on the basis of release of toxic chemicals to the environment. The procedure in Australia is nearly similar through the National Pollutant Inventory requirement (KPMG, 1999).

\section{Corporate environmental reporting in Asian} countries: There are no legal or statutory conditions for companies to disclose environment related information in their annual reports in Asian countries. In Japan, the Japanese Industrial Association KEIDANREN's "Global Environmental Charter" promulgated in 1991, calls for companies to publicize relevant information, carry out educational activities on their measures for preserving the environment and provide users with information on the appropriate use and disposal (including recycling) of their products. In 1996 The Korean Securities Exchange Commission enacted a provision named Corporate Reporting Standards (CAS), which suggested that the companies disclose environmental information in the way of leaving footnotes to their corporate financial reports.

In Bangladesh, there is no statutory or legal requirement for environmental disclosure in annual reports of companies. In Hong Kong, there is no statutory requirement for listed companies to quantify reports and disclose environmental information to the public. Corporate environmental reporting in Sri Lanka is broadly voluntary activities as in Sri Lanka, there is neither a recommended professional standard nor legal framework addressing the issues of corporate environmental reporting. Currently, there is no legal requirement in Malaysia that provides publicly listed companies to disclose environmental information to the public. In Malaysia, the most usually included reported items found in the annual reports of the companies with Corporate Environmental Policy (CEP. However, in spite of having a lack of regulations, it can be seen that a very few dynamic 
corporations are making environmental disclosures in their annual reports fully on a willingly basis.

\section{Corporate environmental reporting: Bangladeshi} scenario: After the end of the British Rule, Bangladesh plunged into a serious series of troubles and communal rules. And Bangladesh was not in a position to pay decent attention to the matters relating to the environment. The First Five Year Plan was implemented with a view to economic development of the country. The Second Five Year Plan designed for industrial development, paid no attention to the harmful consequences of nature that would have to face with the growth of industry. Hence, the plans remained unconcerned about protecting nature. The public attention towards environmental phenomena like environmental pollution, environmental protection and environmental development has grown enormously at the beginning of the mid-nineteenth century.

This is apparent from the contemporary regulatory regime that is being enforced for businesses by the Central and State Government of Bangladesh. Various pieces of legislation have been enacted since mid-70 for the preservation of the environment. In 1977, Environmental Pollution Control Ordinance came into effect to prevent watercourses both surface and underground from pollution. Subsequently, The Environment Conservation Act 1995 was passed. Again in 2000, another act was enacted to protect the environment from pollution that came to be known as the Environment Court Act, 2000 and subsequent amendments. Moreover, from time to time, various rules have been notified to regulate environmental hazardous material, which are: Environmental Pollution Control Ordinance, 1977 The Environment Conservation Act 1995 The Environment Court Act 2010 The Forest Act 1927 The Wildlife Act 2012 The Brick Manufacturing and Brick Kilns Establishment Act 2013 The Bangladesh Biodiversity Act 2017 Environment Policy, 1992 Environment Conservation Act, 1995 and subsequent amendments Environment Conservation Rules, 1997 Environment Court Act, 2000 and subsequent amendments. The National Water Policy, 1999 But, in the context of requiring environment-related information from businesses on a periodic basis, the first public pronouncement was made by the Central Government in 1991 .

The Ministry of Environment and Forest has propounded that "every company shall, in the report of its Board of Directors, reveal shortly the fibrils of compliance with environmental laws, paces taken or proposed to be taken towards acceptance of green technologies for prohibition of pollution, waste minimization, wastage recycling and launching effective pollution control measures, investment on environmental protection and impact of these measures on waste reduction, water and other resource conservation". The Ministry has also examined the Company Laws so that the aforesaid proposal on corporate environmental reporting by the companies could be put into effect. Incidentally, such a proposal did not find a space in the Companies Bill, 1994. As regards the reporting and reporting aspects of environmental protection, some companies in Bangladesh do make policy statements in their annual reports. These are, however, mentioned in the Chairman's or Director's report.

The companies do not disclose any quantitative facts on expenditures incurred, and targets set and achieved. In Bangladesh, the level of environmental related disclosure in the corporate annual reports, both financial and non-financial, is not an encouraging level. Neither the Company Law nor the reporting standard/guidelines issued by the Institute of Chartered Accountants of Bangladesh prescribed disclosure norms for the environment-related matter in the corporate financial statements.

\section{CONCLUSION:}

In different counties, it is mandatory to report environmental issues in the financial disclosures. However most of the companies around the world don't pay much attention to this issue. Now it is the high time to take steps globally and nationally to formulate the reporting and valuation technique as well as the reporting guidelines to incorporate these issues in the corporate reporting and reporting system. It's a matter of great hope that many countries have already taken this issue as an urgent matter and concluded that the voluntary practice should not be 
continued for long. Specific guidelines in the form of standards, rules and regulations should be passed and implemented. It is the only way to ensure equitable treatment towards the environment if the corporations begin to make more environmental costs then environmental liability. To sustain in the corporate world, the corporate should turn their attention towards the longterm sustainability of the environment. And here, the accountants' roles are the key to portrait a permanent solution to this sensitive issue.

\section{ACKNOWLEDGEMENT:}

We are grateful to the Almighty, the merciful and the benevolent Allah who has enabled me to successfully complete the review paper. At the very beginning we would like to express our gratitude to respected: Mr. Mohammed Ali Arshad Chowdhury, Associate Professor, Department of Accounting \& Information Systems, University of Chittagong for helping us to select the subject matter. Finally, we shall be grateful to those persons who will read this paper and who will benefit from this paper at present and in future.

\section{CONFLICTS OF INTEREST:}

The authors whose names are listed above certify that they have NO affiliations with or involvement in any organization or entity with any financial interest.

\section{REFERECES:}

1. Adagye D. I. and Abubakar, S. B. (2018). Developments in Accounting Education and Research: The Environmental Accounting -an Insight. African J. of Accounting and Financial Research, 1(1), 19-32.

2. Ahmad N. N. N. and Sulaiman, M. (2004). Environmental disclosures in Malaysian annual reports: a legitimacy theory perspective. International $j$. of commerce and management, 14(1), 44-59.

3. Bala S. K. and Yusuf, M. A., (2003). Corporate environmental reporting in Bangladesh: a study of listed public limited companies. Dhaka University J. of business studies, 24(1), 31-45.

4. Bennett M. and James, P. (1997): Environment related Management Accoun-ting:
Current Practice and Future Trends. Greener Managt. International, 17, 32-52.

5. Bhate S. (2002). One world, one environment, one vision: are we close to achieving this? An exploratory study of consumer environmental behaviour across three countries. $J$. of Consumer Behaviour: An International Research Review, 2(2), 169-184. https://doi.org/10.1002/cb.98

6. Bose S. (2006). Environmental accounting and reporting in the fossil fuel sector: a study on Bangladesh Oil, Gas and Mineral Corporation (Petrobangla), 34(2), 53-67. https://mpra.ub.uni-muenchen.de/7995/

7. Chowdhury A. A. and Hamid, K. (2013). Present status of corporate environmental accounting (CEA) in Bangladesh: A study based on some selected textile companies. Research J. of Finance and Accounting, 4(17), 122-129.

https://iiste.org/Journals/index.php/RJFA/article/ viewFile/8985/9218

8. Cunningham S. and Gadenne, D. (2003). Do corporations perceive mandatory publication of pollution information for key stakeholders as a legitimacy threat? $J$. of Environmental Assesst. Policy and Managt., 5(04), 523-549. https://doi.org/10.1142/S1464333203001474

9. Fortes H. (2002). The need for environmental reporting by companies. Greener Management International, 40(1), 77-92.

10. Gamble G. O., Hsu, K., Kite, D. and Radtke, R.R. (1995). Environmental disclosures in annual reports and 10Ks: An examination. Accounting Horizons, 9(3), p.34-54.

11. Islam MJ. (2020). Sustainability reporting of banking companies in Bangladesh: a study on environmental aspect, Can. J. Bus. Inf. Stud., 2(2), 35-44. https://doi.org/10.34104/cjbis.020.035044

12. Islam MT, and Alam MJ. (2019). The relationship between informal economy and GDP growth: a study on south-asian developing countries. Can. J. Bus. Inf. Stud., 1(5), 01-09.

https://doi.org/10.34104/cjbis.019.0109 
13. Jones M.J. (2003). Accounting for biodiversity: operationalising environmental accounting. Accounting, Auditing \& Accountability Journal. 16(5), 762-789. https://doi.org/10.1108/09513570310505961

14. Kolk A., Van Tulder, R. and Welters, C. (1999). International codes of conduct and corporate social responsibility: can transnational corporations regulate them-selves? Transnational corporations, 8(1), 143-180.

15. KPMG (2002). International survey of corporate sustainability reporting, ISBN 906990-133-1, 1-37.

16. Lodhia S.K. (2000). Social and environmental reporting in Fiji: A review of recent corporate annual reports. Social and Environmental Accountability Journal, 20(1), 15-18. https://doi.org/10.1080/0969160X.2000.9651627

17. Nuhoglu E. (2003). An exploratory study of website environmental reporting in Turkey. Social and Environmental Accountability Journal, 23(1), 1-5. https://doi.org/10.1080/0969160X.2003.9651685

18. Pramanik A.K., Shil, N.C. and Das, B. (2008). Corporate environmental reporting: An emerging issue in the corporate world. International Journal of Business and management, 3(12), 146-154.

https://doi.org/10.5539/ijbm.v3n12p146

19. Punte S. (1999). KPMG international survey of environmental reporting 1999. KPMG Environmental Consulting.

20. Rahman M.A. and Muttakin, M.B. (2005). Corporate environmental reporting practices in Bangladesh: A study of some selected companies. The Cost and Management, 33(4), 13-21.

21. Rahman MM., and Rahman MS. (2020). Green reporting as a tool of environmental sustainability: some observations in the context of Bangladesh, Int. J. Manag. Account. 2(2), 31-37. https://doi.org/10.34104/ijma.020.031037

22. Rajapakse B. (2003). Environmental reporting practices of the private sector business organizations in Sri Lanka, Journal of Management, 1(1), 11-21.

http://www.seu.ac.lk/researchandpublications/f mc_journal/jmiii/JOURNAL\%202003-2.pdf

23. Romlah J., Takiah, M. and Nordin, M. (2002). An investigation on environmental disclosures: Evidence from selected industries in Malaysia. International Journal of Business and Society, 3(2), 55-68.

24. Shil N.C. and Iqbal, M. (2005). Environmental disclosure: a Bangladesh perspective. Paper No. 7707.

https://mpra.ub.uni-muenchen.de/7707/

25. Shuvro RA, Saha S, and Alam MJ. (2020). Measuring the level of job satisfaction of the employees of Grameen bank: an empirical study, Can. J. Bus. Inf. Stud., 2(1), 1-11. https://doi.org/10.34104/cjbis.020.01011

26. Thompson P. and Zakaria, Z. (2004). Corporate social responsibility reporting in Malaysia: Progress and prospects. Journal of Corporate citizenship, (13), 125-136. https://doi.org/10.9774/GLEAF.4700.2004.sp.00 $\underline{0014}$ 